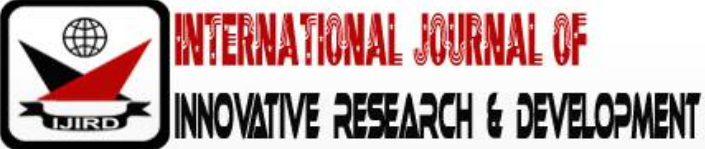

ISSN 2278 - 0211 (Online)

\section{Some Aspects of the Biology of Parachanna Obscura in Kiri Reservoir, Adamawa State, Nigeria}

\author{
Hassan, S.K \\ Lecturer, Department of Biological Sciences, Gombe State University, Nigeria \\ Ja'afaru, A \\ Professor, Department of Zoology, Modibbo Adama University of Technology, Nigeria
}

\begin{abstract}
:
Some aspects of the biology of Parachanna obscura obtained from Kiri Reservoir Adamawa State Nigeria, were studied. Samples were collected from July-December, 2014. A total of 64 Parachanna obscura were collected from fishermen catch and transported to the Laboratory for analysis. Identification of fish was done using Babatunde and Raji (2004). LengthWeight relationship and Condition factor was calculated using Froeze (2006). Stomach contents were analysed using frequency of occurrence Ogbeibu and Ezeunara, (2002). Food materials were identified using keys by Mellanby, (1975). Presence of ovary with or without eggs represent female and testis represent male. Mahmoud, (2009) was used to identify Stages of Gonads Development. Indirect Gravimetric Sub sampling was used in estimating the number of eggs of every female specimen. The Length-Weight analyses showed that the entire fishes exhibited negative allometric growth pattern, with regression exponent values less than 3. Condition factor of Parachannaobscura was approximately 1 . The Stomach content revealed the species are carnivores. There were more females than males, with ratio 1.4:1. Immature fish dominated the catch with Stages of Gonad Development II and III. Fecundity ranged from 1333 to 3000.
\end{abstract}

Keywords: Length-weight, condition factor, feeding habit, sex ratio, gonads, fecundity

\section{Introduction}

Fish makes a vital contribution to the survival and health of a significant portion of the world's population (Bolaji et al., (2011)). Fish is an important source of protein in terms of its nutritional value and affordability especially to the world's poorest people who rely on fish as their primary source of protein (Bolaji et al., 2011). Fish provides most of daily animal protein, nutrients and micronutrients that are essential to cognitive and physical development, especially in children, and are an important part of healthy diet (Adebola et al., 2013). As an affordable animal source of protein in some of the poorest countries, fish is the primary source of nutrition, as a source of income and of which millions depend directly on fisheries and aquaculture for their livelihoods (Adebola et al., 2013).

Fishes especially those of tropical and sub-tropical water systems are known to experience growth fluctuations due to many factors such as environmental changes, food composition changes, competition within the food chain, and changes in the physical and chemical properties of the aquatic medium (Adedeji and Araoye, 2005; Abowei and Davies, 2009).

Various authors have worked on the various aspects of biology of fish over the years, this include the works of Isangedighi and Umoumoh (2011), Bolaji et al., (2011), Olurin and Savage (2011), (Adebola et al., 2013) and many others. This work is aimed at determining the state of physiological wellbeing of the species, the food and feeding habit of the species and the reproductive/ breeding potential of the species.

\section{Materials and Methods}

\subsection{Study area}

Kiri village as shown in Figure 1 is located in Shelleng Local Government Area of Adamawa State. Kiri village lies on Latitude $9^{\circ} 40^{\prime} 47^{\prime \prime}$ north, Longitude $12^{\circ} 0^{\prime} 51^{\prime \prime}$ east on the Southern part of Adamawa State. The reservoir was as a result of a dam that was constructed on river Gongola, Enplan Group (2004). 


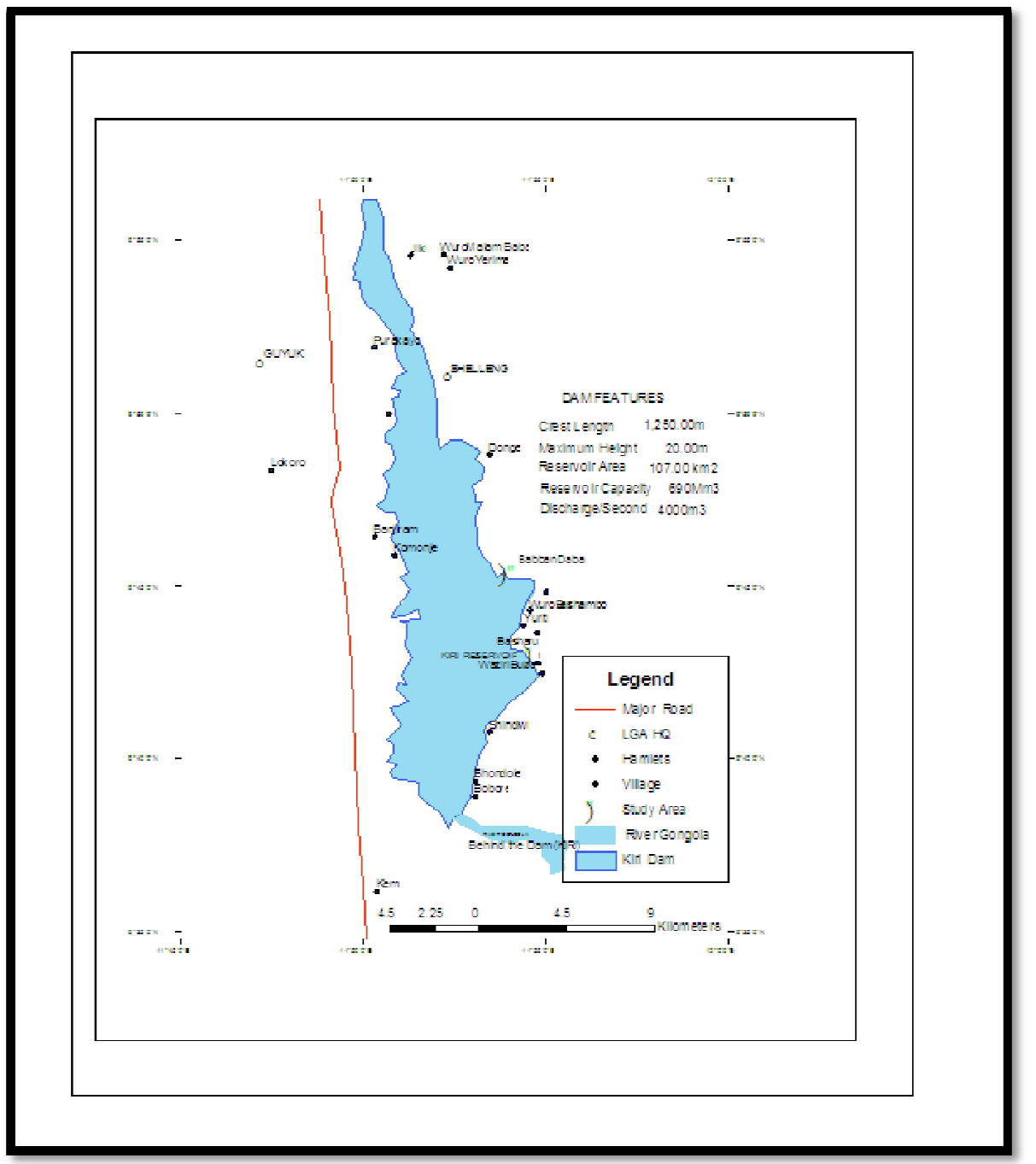

Figure 1: Map of Kiri Reservoir

\subsection{Sampling Procedures}

The taxonomical key for identification of fish by Babatunde and Raji (2004) was used to identify the species.

The length weight relationship and Condition factor of the fish was carried out using the Froeze (2006) methods.

Stomach contents were analysed using frequency of occurrence Ogbeibu and Ezeunara, (2002). The food materials were identified using keys for identification by Mellanby, (1975).

The different sexes of the species were identified after dissection. The presence of ovary, with or without eggs represents the female while testis represents the male.

Taxonomical key of identification by Mahmoud, (2009) was used to identify the stages of gonadal development.

The Indirect Gravimetric Sub sampling was used in estimating the number of eggs of every female specimen. (Bagenal, 1979).

\section{Results}

The results of the measurements of the Total Lengths (TL), Standard Lengths (SL) and Body Weights of Parachanna obscura were found to be 25.0 - $35.0 \mathrm{~cm}, 12.0$ - 24.0 and 161.0 - $263.0 \mathrm{~g}$ respectively,as shown in Table 1.

Log-Length, Log-Weight relationships were calculated for P. obscura for Jul- Dec. The b values obtained were all less than three, an example for the month of July, as shown in Figure 2.

\begin{tabular}{|c|c|c|}
\hline Parameter & Range & Mean \\
\hline Total length $(\mathrm{cm})$ & $25.0-35.0$ & 30.0 \\
\hline Standard length $(\mathrm{cm})$ & $12.0-24.0$ & 18.0 \\
\hline Body weight $(\mathrm{g})$ & $161.0-263.0$ & 212.0 \\
\hline
\end{tabular}

Table 1: Total Length, Standard Length and Body Weight Range Distribution for

Parachanna Obscura Collected from Fish Landed In Kiri Reservoir Jul-Dec. 2014 


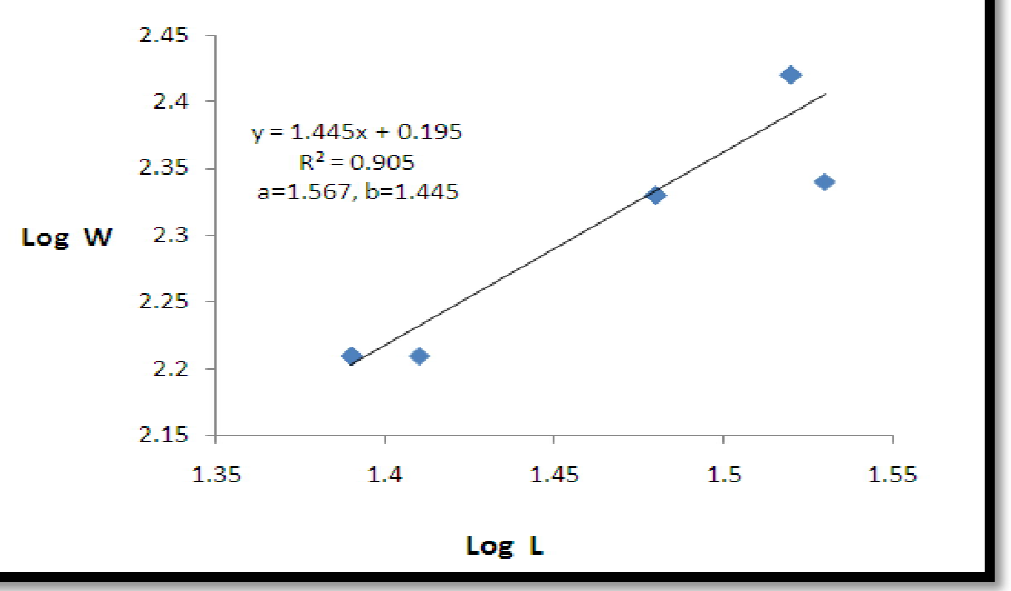

Figure 2: Log-Length and Log-Weight R/ Ship of P. Obscura, For July

The average values of the condition factor $(\mathrm{K})$ are $0.82,0.78,0.85,0.87,0.97$ and 0.83 with $\mathrm{K}$ value of 0.85 (mean) for the month of July to December(Table 2).

\begin{tabular}{|c|c|c|c|c|c|c|}
\hline & July & August & September & October & November & December \\
\hline $\mathrm{X}$ & 9.8 & 9.3 & 8.5 & 1.04 & 9.7 & 6.6 \\
\hline $\mathrm{K}$ & & & 0.85 & & & \\
\hline
\end{tabular}

Table 2: Showing Condition Factor of Parachanna Obscura Collected from

Fish Landed in Kiri Reservoir Jul-Dec. 2014

The result on stomach content of Parachanna obscura shows that twenty one percent (21.88 \%) of the sample had empty stomach while seventy eight percent (78.13\%) had full stomach, (Table 3). The major categories of food substances found in the stomach using frequency of occurrence includes; detritus (100\%), insect part (100\%), pisces (70\%), nematode (72\%), macrophyte material (64\%) and biogenic sand (48\%), as shown in Table 4.

\begin{tabular}{|c|c|c|}
\hline Total Number of Stomach Examined & Full Stomach & Empty Stomach \\
\hline 64 & $50(78.13 \%)$ & $14(21.88 \%)$ \\
\hline
\end{tabular}

Table 3: The Stomach Condition of Parachanna Obscuracollected from Fish Landed In Kiri Reservoir Jul-Dec. 2014

\begin{tabular}{|c|c|c|}
\hline Food Item & Number & Frequency of Occurrence (\%) \\
\hline Detritus & 50 & 100 \\
\hline Insects parts & 50 & 100 \\
\hline Pisces & 35 & 70 \\
\hline Mud/nematode & 36 & 72 \\
\hline Macrophyte material & 32 & 64 \\
\hline Biogenic sand & 24 & 48 \\
\hline
\end{tabular}

Table 4: Frequency of Occurrence of Food Item Consumed by Parachanna Obscura Collected from Fish Landed in Kiri Reservoir Jul-Dec. 2014

The result on sex ratio of Parachanna obscurain Kiri reservoir was found that females were slightly more than males in almost all sampling periods, (Table 5). Mature and immature specimens were found in all the catch, with immature individuals dominating the catch,(Table 6).

\begin{tabular}{|c|c|c|c|}
\hline Month & Female & Male & F:M \\
\hline July & 7 & 5 & $1.4: 1$ \\
\hline August & 9 & 3 & $3: 1$ \\
\hline September & 5 & 5 & $1: 1$ \\
\hline October & 6 & 6 & $1: 1$ \\
\hline November & 6 & 4 & $1.5: 1$ \\
\hline December & 5 & 3 & $1.7: 1$ \\
\hline Total & 38 & 26 & $1.4: 1$ \\
\hline
\end{tabular}

Table 5: Number of Females and Males Parachanna Obscura Collected from

Fish Landed in Kiri Reservoir Jul-Dec. 2014 


\begin{tabular}{|c|c|cc|cc|c|}
\hline Month & Number of fish & \multicolumn{2}{|c|}{ Stage II } & \multicolumn{2}{|c|}{ Stage III } & \multicolumn{2}{c|}{ Stage IV } \\
\hline & & M & F & M & F & M F \\
\hline July & 12 & 0 & 4 & 4 & 4 & \\
\hline August & 12 & 2 & 5 & 1 & 4 & \\
\hline September & 10 & 3 & 2 & 2 & 3 & \\
\hline October & 12 & 2 & 2 & 4 & 4 & \\
\hline November & 10 & 1 & 1 & 2 & 5 & \\
\hline December & 8 & 0 & 0 & 3 & 5 & \multicolumn{2}{|c|}{} \\
\hline
\end{tabular}

Table 6: Monthly Occurrence of Stages of Gonadal Development in Parachanna Obscura Collected from Fish Landed in Kiri Reservoir Jul-Dec. 2014

The monthly fecundityof Parachanna obscura in Kiri reservoir was calculated for each female fish,the values were not high in the study with eggs ranging from 1333 to 3000, Table 7.

\begin{tabular}{|c|c|c|c|c|c|c|}
\hline & July & August & September & October & November & December \\
\hline & 2000 & 3000 & 1833 & 1583 & 1583 & 2000 \\
\hline F & 2000 & 3000 & 1833 & 3000 & 1750 & 1750 \\
\hline & 2000 & 2000 & 1583 & 1333 & 1750 & 1333 \\
\hline & 3000 & 2000 & & 1583 & 1583 & 1833 \\
\hline & & & & & 1750 & 3000 \\
\hline
\end{tabular}

Table 7: Monthly Fecundity Estimate in Parachanna Obscura Collected from Fish Landed in Kiri Reservoir Jul-Dec. 2014

\section{Discussion}

The study revealed that all the fishes investigated exhibited negative allometric growth pattern, with regression analyses exponent $\mathrm{b}$ values less than 3 , meaning that their weight increases at a lesser rate than the cube of their body length, this pattern was reported elsewhere by other researchers such as Anibeze 2000; Odedeyi et al., 2007; Bolaji et al., 2011.

Values of condition factors of Parachanna obscura in Kiri reservoir compared to the values of the same species in river Oshun, (Olurin and Savage (2011))means that there is no stress on the fishpopulation of that species in thereservoir. The values of the condition factor of the fish showed $\mathrm{K}$ value of 0.85 which is approximately 1 and implied that the fishes are in good physiological well-being in the reservoir.

Almost $78 \%$ of the species studied had food in their stomach while $22 \%$ had empty stomach. This was said to be as result of the good feeding strategy of P. obscura, and abundance of food in most part of the year in the reservoir. The occurrence of a high percentage of empty stomachs is a characteristic feature of predatory fishes which is associated with their rapid rate of digesting food. Similarly, higher occurrence of non-empty stomach was due to good feeding strategy of species, and food abundance in most part of the year, Haroon (1998).

There were more females over males which may be a mechanism for population regulation (Fagade et al., 1984). Wide disparities in findings exist in sex ratio among fishes. Olurin and Savage (2011) also found out high number of female to males in Parachanna obscura. Specimens in this study were found to have immature gonads from Jul - Dec. indicating no seasonality in breeding patterns. This tallied with the work of Olurin and Savage (2011) who concluded that immature fish dominated their catch.

The number of eggs produced by fishes has been shown by Nikolsky (1963) to be related to the degree of parental care. Fishes that produce millions of eggs show no parental care.On the other hand, in females that produce one or a few hundred eggs they show a form of parental care (Fryer and Iles, 1972; Fagade and Adebisi, 1979). Fecundity estimates were made for all mature female fish. The eggs range from 1333 to 3000 for Parachanna obscura. Olurin and Savage (2011) also found out fecundity estimates between 1711 and 4000 for Parachanna obscura in River Oshun, Southwest Nigeria.

\section{Conclusion}

Parachanna obscura in Kiri reservoir grows faster in length, as the species exhibited negative allometric growth pattern. Condition factor shows the fishes were in good physiological state of well-being in the reservoir. The fish are carnivorous. Numbers of females slightly outnumbered that of males with immature individuals dominating the catch. Fecundity estimates were not high throughout the period of study.

\section{Acknowledgement}

The researchers are grateful to all those that assisted in the field by providing the samples and those in the laboratory.

\section{References}

i. Abowei, J.F and Davis, A.O. (2009). Some population parameters of Clarotes laticeps (Rupell, 1829) from the fresh water reaches of the Lower Nun River, Niger Delta, Nigeria. A. M. J. Sci. Res. 2: 15 - 19.

ii. Adedeji, R. A. and Araoye, P. A. (2005): Study and characterization in the growth of body parts of Synodontis schall (Pisces; Mochokidae) from Asa Dam, Ilorin, Nigeria. Nigerian Journal of Fisheries (2 and 3): 219 - 244. 
iii. Adebola, O.A., Faturoti, O.E. and Owolabi, D.O. (2013). Food and feeding habit of Synodontis nigrita, valenciennes, 1840 (pisces: mochokidae) in Asejire lake, Nigeria. International Journal of Lakes and Rivers. Vol.6 (1): 1-8.

iv. Anibeze, C.I.P. (2000). Length-weight relationship and relative condition of Heterobranchus longifilis (Valencienness) from Idodo River, Nigeria. Naga, the ICLARM Quart. 23, 34-35.

v. Babatunde, D.O. and Raji, A. (2004). Field guide to Nigerian fresh water fishes. Second edition.

vi. Bagenal, T.B. (1979). Methods for assessment of fish production in freshwater. 3rd. edition. Blackwell Scientific Publication. Oxford, London. $\mathrm{p} 365$.

vii. Bolaji, B.B., Mfon, T. U, and Utibe, D.I (2011). Preliminary study on the aspects of the biology of Snakehead fish, Parachanna obscura in a Nigerian wetland. African Journal of Food, Agriculture, Nutrition and. Development. Vol. 1: 1-4.

viii. Enplan Group (2004). Review of the public sector irrigation in Nigeria. Federal Ministry of Water Resources (UN Food and Agricultural Organization). Retrieved 2010-05-21.

ix. Fagade, S.O. and Adebisi, A. A. (1979). On the fecundity of Chrysichthys nigrodigitatus (Lacepede) of Asejire dam. Oyo State, Nigeria. Nigerian Journal of Science. 1(2): 127 - 131.

x. Fagade, S.O., Adebisi, A.A. and Atanda, A.N (1984). The breeding cycle of Sarethorodon galilaeus in the I.I.T.A. lake, Ibadan, Nigeria. Archive of Hydrobiology. 100(4): 493-500.

xi. Froese, R. (2006). Cube law, condition factor and weight-length relationships: history, meta-analysis and recommendations. J. Appl. Ichthyol., 22, n. 4, p 241-253.

xii. Fryer, G. and Iles, T. D. (1972). The cichlid fishes of the great lakes of Africa, their biology and evolution. Oliver and Boyd, Edinburgh. 641 pp.

xiii. Haroon, A.S. (1998). Diet and feeding ecology of two size of Barbodes gonionotus and Oreochromis species in rice field in Bangladesh. NAGA, the ICLARM Quarterly pp. 13 - 18.

xiv. Isangedighi, I.A and Umoumoh O.E (2011). Some aspect of the reproductive Biology of African Snakehead Parachanna obscura in Itu- Cross River system. Nigerian journal of Agriculture, Food and Environment. 7(4) 19-30.

xv. Mahmoud, H.H., (2009). Gonadal maturation and histological observations of Epinephelus areolatus and Lethrinus nebulosus in Halaieb/ Shalatein area, Red sea, Egypt. Global veterinaria, 3: 414-423.

xvi. Mellanby, H. (1975). Animal Life in Freshwater 6th ed. A guide to Freshwater Invertebrates. Chapman and Hall, London. 323p.

xvii. Nikolsky, G.V. (1963). The ecology of fishes. Academic Press. London 352pp.

xviii. Odedeyi, O.O., Fagbenro, O., Bello-Olusoji, O. and Adebayo, O. (2007). Length- weight relationship and condition factor of the elephant fish, Mormyrus rume in River Osse, South Western Nigeria. Animal Research International. Vol. 4 (1): $617-620$.

xix. Ogbeibu, A.E. and Ezeunara P.U. (2002) Ecological impact of brewery effluent on the Ikpoba river, Nigeria, using the fish communities as bio- indicators. Journal of Aquatic Science. 17: 35-44.

xx. Olurin, K.B and Savage O.D (2011). Reproductive Biology, Length- weight relationship and Condition factor of the African snakehead, Parachanna obscura, from River Oshun, South-west Nigeria. International journal of Fisheries and Aquaculture. Vol. 3 (8), pp 146-150. 